\title{
THE USE OF TOTAL QUALITY MANAGEMENT PRACTICES FOR HALALAN TOYYIBAN OF HALAL FOOD PRODUCTS: EXPLORATORY FACTOR ANALYSIS
}

\author{
Rizuwan Abu Karim, Nurazree Mahmud, \\ Najihah Hanisah Marmaya and Helmy Fadlisham Abu Hasan \\ Faculty of Business and Management, \\ Universiti Teknologi MARA Melaka, Malaysia. \\ E-mail: rizuwan305@uitm.edu.my; nurazree642@uitm.edu.my; \\ najihah@uitm.edu.my; helmyfadlisham@uitm.edu.my
}

\begin{abstract}
Much has been written on the influence of total quality management (TQM) towards ensuring quality of food products. To date, however, there seems to be lack of research examining the influence of TQM practices towards halalan toyyiban of halal food products. Based on the Malcom Baldrige National Quality Awards (MBNQA) model, strategic planning, information management, top management, process management, human resource and customer focus were the six dimensions of TQM practices proposed in this study. A total of 128 certified halal food manufacturers were involved in this study. Exploratory factor analysis (EFA) was applied to extract TQM practices. Findings indicated that strategic planning, information management, top management, process management, human resource and customer focus are six dimensions of TQM practices that can assure halalan toyyiban of halal food products.
\end{abstract}

Keywords: TQM, halalan toyyiban, MBNQA, EFA

$\underline{\text { ARTICLE INFO }}$

Article History:

Received: 3 August 2019

Accepted: 11 February 2020

Published: 30 April 2020 


\section{INTRODUCTION}

Halalan toyyiban merely means allowed and permissible for consumption in relation to Shariah law as long as they are safe and not harmful. The opposite of halal is haram/ non-halal which means forbidden and prohibited. Any food or drink which lies within the grey area and does not fall clearly under the halal or non-halal category is classified as 'Syubhah', alternatively called questionable or dubious. In this category, until the status becomes clear, Muslims should avoid consuming Syubhah food or drinks (Riaz \& Chaudry, 2004).

Halalan toyyiban of halal food products does not stop at the Islamic way of slaughtering of animals. But it is a more holistic concept where safe and hygienic guidelines must be adhered to by food manufacturers (Bidin, 2013). In addition, Syed Marzuki, Hall, and Ballantine (2012) pointed out that Shariah compliance and safety of food are two attributes of halalan toyyiban. According to Yusuf Ali (2005), toyyib means wholesome, pure, and clean and nourishing and toyyibbah means wholesome because it is safe for consumers' health (Yaakob, Jamil, Awis Qurni, \& Ahmad Nizam, 2007).

Currently, the implementation of Shariah standards for halal food products by food manufacturers is related to production, packaging, storage and transportation (Mohd Janis, 2004). However, Che Din and Daud (2014) and Abdul Talib, Mohd Ali, and Idris (2013) recommended that total quality management (TQM) practices and Shariah standards should be implemented together in the process of halal food production. In addition, a quality management system from the Islamic perspective or known as MS 1900:2005 emphasizes that management aspect such as strategic planning, information management, top management, process management, human resource and customer focus must be implemented by food manufacturers if they want to produce Shariah compliant products.

Although the implementation of TQM can influence product quality and food safety system, the implementation of these practices among food manufacturers in Malaysia is still low (Che Din \& Daud, 2014; Abdul Talib, Mohd Ali, \& Idris, 2013). Thus, the present study contributes to the body of literature by proposing dimensions of TQM practices that can assure halalan toyyiban of halal food products. 


\section{LITERATURE REVIEW}

\section{Definition of Total Quality Management (TQM)}

In general, the term TQM was used purposively to manage total quality in an organization (Evans \& Lindsay, 1999). For a clearer definition of TQM, Ho (1995, p.4) defined TQM as follows:

"total" means everyone associated with the company is involved in continuous improvement (including its customers and suppliers if feasible);

"quality" means customers expressed and implied requirements are met fully;

"management" means executives are fully committed.

Although there are many definitions of TQM, scholars emphasized that TQM definitions are founded on three principles namely customer focus, continuous improvement and teamwork (Evans \& Lindsay, 1999; Dean \& Bowen, 1994).

The primary principle of TQM is customer focus. Customer focus is related to how the organization satisfies customer needs and wants. It can be achieved through establishing direct contact with customers, gathering information on customers and regularly measuring customer satisfaction (Dean \& Bowen, 1994).

The second principle of TQM is continuous improvement. The purpose of continuous improvement is to produce high quality products. It can be done through the application of statistical process control and cost-and-quality analysis in the production process. These tools can help manufacturers to evaluate the performance of the production process (Dale \& Cooper, 1994).

The third principle is teamwork. Teamwork refers to collaboration among all employees in the organization. To develop teamwork, teambuilding techniques such as role clarification and feedback can be implemented in an organization (Dean \& Bowen, 1994). 
TQM is a holistic management philosophy which focuses on continuous improvement in every function and process within the organization (Dale \& Cooper, 1994). Au and Choi (1999) regarded TQM as an enabler to the organization to satisfy customer needs through producing high quality products. According to Oakland (1993), the organization can achieve a higher level of competitiveness if they implement TQM.

TQM nowadays emphasizes more on employee involvement, commitment and teamwork. The success of any TQM programme is highly dependent on employee involvement. Competent and dedicated employees can help an organization to improve quality of the product (Welikaka \& Sohal, 2008).

\section{Evolution of TQM for Food Products}

The evolution of food quality inspection in food companies has shifted from traditional methods to the total quality management method. Previously, during the Middle Ages in Europe, the quality of food products was determined based on the output of final food products. Certain desired characteristics were measured, examined and compared to assess the conformity of the final food products. For example, bread was tested based on grain quality, weight and amount of the butter. Then, in the middle of the eighteenth century, responsibility to determine the quality of the final food product was assigned to the quality department. The quality inspector was responsible to handle and monitor the quality of food products in the production plant. To any non-conforming product, the quality inspector will remove it from the production line and the quality of food products was achieved through removing defect products by inspection. So, the objective of the food production process was based on quantity and not on quality. This is because the manufacturing process was driven by technology and not based on customer needs and wants (Evans \& Lindsay, 2004).

Due to the complexity of the agri-food supply chain and consumers' desire for safety and quality of food products had also increased. Quality control and quality improvement was used at the beginning of the $20^{\text {th }}$ century. Quality control formed the basis of several quality assurance systems. Meanwhile quality improvement encompassed basic principles of TQM. The implementation of TQM is to assure quality of food products 
by reduction of uncertainty and variability in the design and manufacturing process. So the focus of TQM practices is to ensure customer satisfaction. It can be achieved by producing safety and quality of food product (Luning, Marcellis, \& Van der Spiegel, 2006).

\section{TQM Practices for Achieving Safety of Food Products}

Che Din and Daud (2014) determined six factors regarding TQM practices for achieving safety of halal food products namely top management, strategic planning, customer focus, human resources, process management and information management. Psomas, Vouzas, and Dimitrios (2013) using a sample of Greek food companies, reached the conclusion that two aspects of TQM - the "soft" and "hard" TQM elements have a significant impact on the safety of food products. Furthermore, Psomas and Fotopoulos (2010) identified four critical success factors of TQM implementation which can ensure safety of food products namely top management, employees, customer focus, and process management. Alsaleh (2007) studied 83 food processing and manufacturing companies in Saudi Arabia and stated that willingness of these companies to adopt some quality systems such as the control chart, run chart, histogram, pareto chart and cause and effect chart throughout the food production process starting from receiving the raw materials until packaging of the food products will ensure safety of the food products. Results of his study revealed that there is evidence of the adoption of TQM tools among the Saudi food processing and manufacturing companies. Barendsz (1998) in his food safety and TQM paper review insisted that TQM implementation can facilitate the effective implementation of Hazard Analysis Critical Control Points (HACCP) and International Organization for Standardization (ISO). He recommended that TQM, HACCP and ISO should be jointly implemented by food manufacturers to meet with the demand for safer food.

\section{TQM Constructs in this Study}

Numerous studies on TQM have examined different TQM constructs (Prajogo \& Sohal, 2004). Thus, it is difficult to reach a common set of TQM practices (Hoang, Igel, \& Laosirihongthong, 2006). However, Quality Award models such as the Malcom Baldridge National Quality Award (MBNQA) (2005) are considered essential in providing a solid foundation of TQM 
practices for ensuring successful implementation of Shariah compliance (Mohd Mokhtar, Zien Yusoff, Abas, Ahmad, Md Hussain, \& Othman, 2013).

Historically, the MBNQA was introduced by President Reagen in the United States (U.S.). Recognizing that productivity of the U.S. was declining, President Reagan signed legislation mandating a national study and conference on productivity in October 1982. In conjuction with this conference, the "National Quality Award", similar to the Deming Prize in Japan, was proposed to be awarded annually to those firms that successfully challenge and meet the award requirements. These requirements and the accompanying examination process should be very similar to the Deming Prize system. The main purpose of the MBNQA was to stimulate the American companies to improve their quality and productivity. Another objective was to recognizing the achievements of those companies that improve the quality of their goods and services (Evans \& Lindsay, 2005).

Most of the organizations have applied the quality awards models such as Deming Prize, the MBNQA and the European Quality Award (EQA) as their TQM practice (Bou-Llusar, Esrig-Tena, Roca-Puig, \& Beltran-Martin, 2009). In addition, many countries have referred to the MBNQA and EQA when modelling their national quality awards (Sharma \& Kodali, 2008). According to Evans and Lindsay (2004), there are six elements underpinning the MBNQA namely:

1. Top management. This category examines how an organization's senior leaders address values, direction and performance expectations, as well as a focus on customers and other stakeholders, empowerment, innovation and learning. Also examined are how an organization addresses its responsibilities to the public and supports its key communities.

2. Strategic planning. This category examines how an organization develops its strategic objectives and action plans. Also examined are how chosen strategic objectives and action plans are deployed and how progress are measured.

3. Customer focus. This category examines how an organization determines requirement, expectations and preferences of customers 
and markets. Also examined are how the organization builds relationship with customers, determines the key factors that lead to customer acquisition, satisfaction and retention and to business expansion.

4. Information management. This category examines an organization's information management and performance measurement systems and how the organization analyzes performance data and expansion.

5. Human resource. This category examines how an organization motivates and enables employees to develop and utilize their full potential in alignment with the organization's overall objectives and action plans. Also examined is the organization's effort to build and maintain a work environment and an employee support climate conducive to performance excellence and to personal and organizational growth.

6. Process management. This category examines the key aspects of an organization's process management including customer-focused design, product and services delivery, key business and support process. This category encompasses all key process and all work units.

There are many advantages of using the MBNQA framework as the multi dimension of TQM practices. First, it covers major elements usually used by practitioners and researchers in quality management practices (Dean \& Bowen, 1994). Second, the MBNQA criteria has always been updated and revised to include the latest developments in quality management (Tai \& Przasnyski, 1999).

Third, it integrated different ideas of quality gurus such as Deming and Juran (Dean \& Bowen, 1994). According to Curkovic, Melnyk, Calantone, and Handfield (2000), the MBNQA criteria are synonymous with TQM practices because its criteria have incorporated the main elements of TQM which has been proposed by well known TQM scholars such as Deming (1986) Garvin (1983) and Juran and Gryna (1980). Fourth, more than 56 national and international quality awards criteria have adapted the MBNQA elements (De Baylo, 1999). Fifth, it explains both the soft and hard elements of TQM. The soft side includes customers, employees and leadership. 
Meanwhile, the hard side captures technical aspects to increase production of a company (Wilkinson, Allen, \& Snape, 1991). Sixth, following Sila and Ebrahimpour (2003), although the MBNQA was originally introduced in the U.S., numerous studies were conducted in different countries by using the MBNQA model such as in New Zealand, in Malaysia, in Mexico and in Australia.

Hence, based on the above explanation, top management, strategic planning, customer focus, information management, human resources and process management are six dimensions of TQM practices in this study.

\section{RESEARCH METHODOLOGY}

\section{Questionnaire}

In order to determine latent constructs of TQM practices for halalan toyyiban of halal food products, this study was carried out exclusively on the halal food sector. The measurement scale for TQM practices used in this study was based on an adaptation of the scale developed by Lam, Lee, Ooi, and Phusavat (2012), Prajogo (2006) and Prajogo and Sohal (2006). The reason for the selection of these measurement scales is because these measurement scales comprised the criteria of the MBNQA that were used as the basis of this study. There are twenty three items which are grouped into six TQM constructs in this study and a five-point Likert scale, ranging from (1) strongly disagree to (5) strongly agree were applied to measure each item. The rationale of applying the five-point Likert scale was because studies conducted by many authors demonstrated considerable sensitivity and validity. Besides that, the modification was done to original items to fit the need of this study. Table 1 illustrates items which made up each construct. 
Table 1: Construct Operationalization, Sources of Scale Items and Types of Scale Measurement for TQM Practices

\begin{tabular}{|c|c|c|c|c|}
\hline Construct & $\begin{array}{l}\text { No. of } \\
\text { Item }\end{array}$ & Operationalization of Variables & Source & Scale \\
\hline $\begin{array}{l}\text { Strategic } \\
\text { planning }\end{array}$ & 4 & $\begin{array}{l}\text { 1. Our organization has a written } \\
\text { statement of halal food/ } \\
\text { beverages strategy } \\
\text { 2. Our organization believes } \\
\text { that our halal food/beverages } \\
\text { business strategy are linked to } \\
\text { quality values } \\
\text { 3. The vision and mission of our } \\
\text { organization is to improve halal } \\
\text { food/beverages sales } \\
\text { 4. Our organization always } \\
\text { incorporates supplier capabilities } \\
\text { to provide Shariah compliant raw } \\
\text { materials }\end{array}$ & $\begin{array}{l}\text { Adapted from } \\
\text { Lam et al., } \\
\text { (2012), Prajogo, } \\
\text { (2006) and } \\
\text { Prajogo and } \\
\text { Sohal (2006) }\end{array}$ & $\begin{array}{l}\text { 5-Point } \\
\text { Likert } \\
\text { Scale }\end{array}$ \\
\hline $\begin{array}{l}\text { Information } \\
\text { management }\end{array}$ & 4 & $\begin{array}{l}\text { 1. Our organization has knowledge, } \\
\text { availability, access and collection } \\
\text { of halal food/beverages data } \\
\text { 2. Our organization regularly } \\
\text { reviews quality performance of } \\
\text { halal food/beverages } \\
\text { 3. Our organization has availability } \\
\text { of sales performance figures for } \\
\text { analysis and decision making on } \\
\text { halal food/beverages } \\
\text { 4. Our organization has knowledge } \\
\text { of lost of halal food/beverages } \\
\text { customers and investigates } \\
\text { reason }\end{array}$ & $\begin{array}{l}\text { Adapted from } \\
\text { Lam et al., } \\
\text { (2012), Prajogo, } \\
\text { (2006) and } \\
\text { Prajogo and } \\
\text { Sohal (2006) } \\
\end{array}$ & $\begin{array}{l}\text { 5-Point } \\
\text { Likert } \\
\text { Scale }\end{array}$ \\
\hline $\begin{array}{l}\text { Top } \\
\text { management }\end{array}$ & 4 & $\begin{array}{l}\text { 1. Top management actively } \\
\text { participates in halal food/ } \\
\text { beverages procedures } \\
\text { 2. Top management learns quality- } \\
\text { related concepts of halal food/ } \\
\text { beverages and skills of the halal } \\
\text { certification process } \\
\text { 3. Top management strongly } \\
\text { encourages em ploye e } \\
\text { involvement in quality } \\
\text { management and improvement } \\
\text { activities of halal food/beverages } \\
\text { 4. Top management empowers } \\
\text { employees to solve quality } \\
\text { problems of halal food/beverages }\end{array}$ & $\begin{array}{l}\text { Adapted from } \\
\text { Lam et al., } \\
\text { (2012), Prajogo, } \\
\text { (2006) and } \\
\text { Prajogo and } \\
\text { Sohal (2006) }\end{array}$ & $\begin{array}{l}\text { 5-Point } \\
\text { Likert } \\
\text { Scale }\end{array}$ \\
\hline
\end{tabular}




\begin{tabular}{|c|c|c|c|c|}
\hline Construct & $\begin{array}{l}\text { No. of } \\
\text { Item }\end{array}$ & Operationalization of Variables & Source & Scale \\
\hline $\begin{array}{l}\text { Process } \\
\text { management }\end{array}$ & 3 & $\begin{array}{l}\text { 1. Employees work as a team in } \\
\text { producing halal food/beverages } \\
\text { product but guided by clear goals } \\
\text { 2. Employees understand their } \\
\text { respective roles in producing } \\
\text { halal food/beverages products } \\
\text { 3. Employees are encouraged to } \\
\text { develop new and innovative } \\
\text { ways for better performance in } \\
\text { producing halal food/beverages } \\
\text { products }\end{array}$ & $\begin{array}{l}\text { Adapted from } \\
\text { Lam et al., } \\
\text { (2012), Prajogo, } \\
\text { (2006) and } \\
\text { Prajogo and } \\
\text { Sohal (2006) }\end{array}$ & $\begin{array}{l}\text { 5-Point } \\
\text { Likert } \\
\text { Scale }\end{array}$ \\
\hline $\begin{array}{l}\text { Human } \\
\text { resource }\end{array}$ & 4 & $\begin{array}{l}\text { 1. Our organization maintains a work } \\
\text { environment that contributes to } \\
\text { the health, safety and well-being } \\
\text { of all employees in producing } \\
\text { halal food/beverages } \\
\text { 2. Our organization has maintained } \\
\text { both "top-down" and "bottom- } \\
\text { up" communication process in } \\
\text { producing halal food/beverages } \\
\text { product } \\
\text { 3. Employee satisfaction in } \\
\text { producing halal food/beverages } \\
\text { product is formally and regularly } \\
\text { measured } \\
\text { 4. Our organization has encouraged } \\
\text { training and development on the } \\
\text { halal certification system and its } \\
\text { application process for all our } \\
\text { employees }\end{array}$ & $\begin{array}{l}\text { Adapted from } \\
\text { Lam et al., } \\
\text { (2012), Prajogo, } \\
\text { (2006) and } \\
\text { Prajogo and } \\
\text { Sohal (2006) } \\
\end{array}$ & $\begin{array}{l}\text { 5-Point } \\
\text { Likert } \\
\text { Scale }\end{array}$ \\
\hline $\begin{array}{l}\text { Customer } \\
\text { focus }\end{array}$ & 4 & $\begin{array}{l}\text { 1. Our organization provides } \\
\text { warranty on our halal food/ } \\
\text { beverages products } \\
\text { 2. Suggestions from customers } \\
\text { who bought halal food/beverages } \\
\text { product is an input to our } \\
\text { organization } \\
\text { 3. Halal food/beverages quality- } \\
\text { related customer complaints are } \\
\text { treated with top priority } \\
\text { 4. Our organization always } \\
\text { conducts halal food/beverages } \\
\text { market research in order to } \\
\text { collect suggestions for improving } \\
\text { quality our products }\end{array}$ & $\begin{array}{l}\text { Adapted from } \\
\text { Lam et al., } \\
\text { (2012), Prajogo, } \\
\text { (2006) and } \\
\text { Prajogo and } \\
\text { Sohal (2006) } \\
\end{array}$ & \\
\hline
\end{tabular}




\section{Translation Process}

As explained earlier, the current survey instrument employed establishment measurement and scale derived from past literature and all the measurements used were written in English. Since this study was conducted in Malaysia and all the samples of this research are non-English speakers, translation from English to Malay was needed to ensure that the respondents will provide the right answer to the questions in this study.

\section{Pre-Testing}

For the purpose of ensuring that all questions contained in the questionnaire were appropriate and sufficient in measuring variables presented in this study, opinion and advice were sought from an assistant director for the halal hub division from Jabatan Kemajuan Islam Malaysia (JAKIM), an assistant director for halal department from Majlis Agama Islam Negeri Sembilan (MAIN), a halal officer from Jabatan Agama Islam Melaka (JAIM) and a halal officer from Jabatan Agama Islam Selangor (JAIS). These subjects were chosen because they are continuously participating in the halal food Shariah compliance management. To further enhance all aspects of the questionnaire including question content, wording, sequence, form and layout as well as question difficulty, this study also conducted a pre-test with one academician from Hotel Management (Restaurant Management), Universiti Teknologi Mara (UiTM), Melaka and another from the Business Faculty, UiTM, Melaka. The feedback received from the academicians was used for improving the questionnaire by identifying and eliminating potential problems.

\section{Analysis}

According to Awang (2012), to obtain the dimensions for every construct, the researcher can perform an exploratory factor analysis (EFA). As such, in this study on the multidimensionality of TQM constructs were subjected to an EFA analysis. Hair, Anderson, Tatham, and Black (1998) stated, "a basic assumption of factor analysis is that some underlying structure does exist in the set of selected variables. It is the responsibility of the researcher to ensure that the observed patterns are conceptually valid and appropriate for the study with factor analysis (p. 100). 


\section{RESULTS}

\section{Respondents Profile}

The population of this study was certified halal food manufacturers in Selangor and Malacca and the sample was randomly selected. Data was collected through a structured questionnaire. As shown in Table 2, the majority of respondents were from the SMEs industry (86) and followed by micro-enterprises (42). Their percentage was 67.2 percent and 32.8 percent respectively. In terms of the scheme of certification, a total of 116 respondents (90.6 percent) were categorized as food and beverages. Meanwhile eight respondents (6.3 percent) were in the beverages only category and four respondents (3.1 percent) were in the food only category. In relation to the designation of respondents, most of the respondents were halal supervisors ( 74 respondents, 57.8 percent), followed by halal committee (39 respondents, 30.5 percent), production supervisors (12 respondents, 9.4 percent) and managers ( 3 respondents, 2.3 percent). Table 2 also shows the majority of respondents had operating experience of more than five years (57 respondents, 44.5 percent). In the meantime, the second highest respondents in terms of years of operating were between three to four years (50 respondents, 39.1 percent) and respondents with the number of operating experience between one to two years were only 21 respondents with 16.4 percent. In terms of location of respondents, the majority of respondents were from Melaka ( 81 respondents, 63.3 percent) and followed by Selangor (47 respondents, 36.7 percent).

Table 2: Respondent Background Information

\begin{tabular}{lcc}
\multicolumn{1}{c}{ Demographic } & Frequency & Percentage \\
\hline Type of Industry & & \\
Microenterprises & 42 & 32.8 \\
Small and medium industry & 86 & 67.2 \\
Scheme of certification & & \\
Food only & 4 & 3.1 \\
Beverages only & 8 & 6.3 \\
Food and beverages only & 116 & 90.6
\end{tabular}




\begin{tabular}{lcc}
\multicolumn{1}{c}{ Demographic } & Frequency & Percentage \\
\hline $\begin{array}{l}\text { Designation of respondent } \\
\text { Manager }\end{array}$ & 3 & 2.3 \\
Halal committee & 39 & 30.5 \\
Halal supervisor & 74 & 57.8 \\
Production supervisor & 12 & 9.4 \\
Year operating & & \\
1-2 years & 21 & 16.4 \\
3-4 years & 50 & 39.1 \\
More than 5 years & 57 & 44.5 \\
Location of respondents & & \\
Selangor & 47 & 36.7 \\
Melaka & 81 & 63.3 \\
\hline
\end{tabular}

\section{Exploratory Factor Analysis (EFA)}

In this study the EFA analysis were carried out to categorize which items were suited to be composed of the same component. The data was analysed using the SPSS version 21. By using the data collected based on the sampling used, EFA was applied to extract the latent construct by using principal axis factoring (PAF) with direct oblimin rotation. The results in Table 3 indicate that the Bartletts' Test of Sphericity is significant $(\mathrm{p}<0.05)$. Furthermore, the measure of sampling adequacy by Kaiser-Meyer-Olkin (KMO) is excellent since it exceeded the required value of 0.5 (Hair et al., 1998). These two results indicated that the data is adequate to proceed with the data reduction procedure in EFA (Hoque et al., 2018).

Table 3: The KMO and Bartlett's Test

\begin{tabular}{lcc}
\hline $\begin{array}{l}\text { Kaiser-Meyer-Olkin Measure of } \\
\text { Sampling Adequacy }\end{array}$ & .903 \\
\hline Bartlett's Test of Sphericity & Approx. Chi-Square & 3808.015 \\
& Df & 253 \\
& Sig. & .000 \\
\hline
\end{tabular}

To determine the underlying dimensions of TQM practices, based on a computed Eiganvalue greater than 1.0, there were final six latent factors are established (Table 4). The Eiganvalue ranged between 4.208 and 2.548. The variance explained for component 1 was 18.30 percent, component 2 was 14.29 percent, component 3 was 13.16 percent, component 4 was 12.74 
percent, component 5 was 11.54 percent and component 6 was 11.08 percent. The total variance explained for measuring this construct was 81.11 percent. The total variance explained was acceptable since it exceeded the minimum 60 percent and can be considered for further analysis (Awang, 2012).

Table 4: Total Variance Explained

\begin{tabular}{cccc}
\hline Component & Total & $\%$ of Variance & Cumulative $\%$ \\
\hline 1 & 4.208 & 18.295 & 18.295 \\
2 & 3.287 & 14.292 & 32.587 \\
3 & 3.027 & 13.159 & 45.746 \\
4 & 2.931 & 12.742 & 58.489 \\
5 & 2.654 & 11.540 & 70.029 \\
6 & 2.548 & 11.077 & 81.106 \\
\hline
\end{tabular}

Based on Table 3 and Table 4, a final six latent factors for TQM practices are established with the Kaiser-Meyer-Olkin $=0.903$ and significant Bartlett's test of sphericity, $\mathrm{p}<0.05$, explaining 81.11 percent of the total variance. Furthermore, Table 5 presents 23 items having a factor loading above 0.5 . According to Hair et al. (1998), the factor loading should be greater than 0.5 in order to be retained (Hair et al., 1998). As a result, they are named after the items that are loaded on them, such as strategic planning (factor loadings between 0.821 and 0.695), information management (factor loadings between 0.838 and 0.646 ), top management (factor loadings between 0.885 and 0.523 ), process management (factor loadings between 0.829 and 0.526 ), customer focus (factor loadings between 0.769 and 0.555 ) and human resource (factor loadings between 0.656 and 0.586 ).

Table 5: Summary of Factor Analysis Results for TQM Practices

\begin{tabular}{cccccccc}
\hline \multirow{2}{*}{ Items } & Factor & Factor & Factor & Factor & Factor & Factor \\
& 1 & $\mathbf{2}$ & $\mathbf{3}$ & $\mathbf{4}$ & $\mathbf{5}$ & $\mathbf{6}$ \\
\hline
\end{tabular}

\section{Strategic Planning}

The vision and mission of our 0.821 organization is to improve halal food/ beverages sales

Our organization believes that our halal food/beverages business strategy are linked to quality values 


\begin{tabular}{|c|c|c|c|c|c|c|}
\hline Items & $\begin{array}{c}\text { Factor } \\
1\end{array}$ & $\begin{array}{c}\text { Factor } \\
2\end{array}$ & $\begin{array}{c}\text { Factor } \\
3\end{array}$ & $\begin{array}{c}\text { Factor } \\
4\end{array}$ & $\begin{array}{c}\text { Factor } \\
5\end{array}$ & $\begin{array}{c}\text { Factor } \\
6\end{array}$ \\
\hline $\begin{array}{l}\text { Our organization has a written } \\
\text { statement of halal food/beverages } \\
\text { strategy }\end{array}$ & 0.726 & & & & & \\
\hline $\begin{array}{l}\text { Our organization always incorporates } \\
\text { supplier capabilities to supply Shariah } \\
\text { compliant raw materials }\end{array}$ & 0.695 & & & & & \\
\hline \multicolumn{7}{|l|}{ Information Management } \\
\hline $\begin{array}{l}\text { Our organization regularly reviews } \\
\text { on quality performance of halal food/ } \\
\text { beverages }\end{array}$ & & 0.838 & & & & \\
\hline $\begin{array}{l}\text { Our organization has availability of } \\
\text { sales performance figures for analysis } \\
\text { and decision making on halal food/ } \\
\text { beverages }\end{array}$ & & 0.720 & & & & \\
\hline $\begin{array}{l}\text { Our organization has knowledge, } \\
\text { availability, access and collection of } \\
\text { halal food/beverages data }\end{array}$ & & 0.671 & & & & \\
\hline $\begin{array}{l}\text { Our organization has knowledge } \\
\text { of loss of halal food/beverages } \\
\text { customers and investigates reason }\end{array}$ & & 0.646 & & & & \\
\hline
\end{tabular}

\section{Top Management}

Top management learns qualityrelated concepts of halal food/ beverages and skills of the halal certification process

Top management actively participates in the halal food/beverages procedure Top management strongly encourages employee involvement in quality management and improvement activities of halal food/beverages

Top management empowers employees to solve quality problems of halal food/beverages

\section{Process Management}

Employees are encouraged to develop new and innovative ways for better performance in producing halal food/ beverages product

Employees work as a team in producing halal food/beverages product but guided by clear goals

Employees understand their respective roles in producing halal food/beverages product 


\begin{tabular}{|c|c|c|c|c|c|c|}
\hline Items & $\begin{array}{c}\text { Factor } \\
1\end{array}$ & $\begin{array}{c}\text { Factor } \\
2\end{array}$ & $\begin{array}{c}\text { Factor } \\
3\end{array}$ & $\begin{array}{c}\text { Factor } \\
4\end{array}$ & $\begin{array}{c}\text { Factor } \\
5\end{array}$ & $\begin{array}{c}\text { Factor } \\
6\end{array}$ \\
\hline \multicolumn{7}{|l|}{ Customer Focus } \\
\hline $\begin{array}{l}\text { Halal food/beverages quality-related } \\
\text { customer complaints are treated with } \\
\text { top priority }\end{array}$ & & & & & 0.769 & \\
\hline $\begin{array}{l}\text { Suggestions from customers who } \\
\text { bought halal food/beverages product } \\
\text { is an input to our organization }\end{array}$ & & & & & 0.742 & \\
\hline $\begin{array}{l}\text { Our organization always conducts } \\
\text { halal food/beverages market research } \\
\text { in order to collect suggestions for } \\
\text { improving the quality our products }\end{array}$ & & & & & 0.570 & \\
\hline $\begin{array}{l}\text { Our organization provides warranty } \\
\text { on our halal food/beverages products }\end{array}$ & & & & & 0.555 & \\
\hline \multicolumn{7}{|l|}{ Human Resource } \\
\hline $\begin{array}{l}\text { Employee satisfaction in producing } \\
\text { halal food/beverages product is } \\
\text { formally and regularly measured }\end{array}$ & & & & & & 0.656 \\
\hline $\begin{array}{l}\text { Our organization has encouraged } \\
\text { training and development on the halal } \\
\text { certification system and its application } \\
\text { process for all our employees }\end{array}$ & & & & & & 0.639 \\
\hline $\begin{array}{l}\text { Our organization has maintained } \\
\text { both "top-down" and "bottom-up" } \\
\text { communication process in producing } \\
\text { halal food/beverages product }\end{array}$ & & & & & & 0.629 \\
\hline $\begin{array}{l}\text { Our organization maintains a work } \\
\text { environment that contributes to the } \\
\text { health, safety and well-being of all } \\
\text { employees in producing halal food/ } \\
\text { beverages }\end{array}$ & & & & & & 0.586 \\
\hline
\end{tabular}

\section{CONCLUSION}

Even though the importance of Shariah compliance of halal food products these days has been extensively acknowledged in the literature, there is little and most likely no previous study that had examined the multidimensionality of TQM practices for halalan toyyiban of halal food products. This research explored the gaps and findings of this study indicated that strategic planning, information management, top management, process management, customer focus and human resource are six dimensions of TQM practices which could be implemented by certified halal food manufacturers in Malaysia. 
However, in this study, there are some limitations that give rise to a number of suggestions for future research. Given the small sample size and the few states (e.g. Selangor and Kelantan) represented in this study, it is recommended that future research further analyzes a broader sample size.

\section{REFERENCES}

Abdul Talib, H. H., Mohd Ali, K. A., \& Idris, F. (2013). Quality management framework for the SMEs food processing industry in Malaysia. International Food Research Journal, 20(1), 147-164.

Alsaleh, N. A. (2007). Application of quality tools by the Saudi food industry. The TQM Magazine, 19(2), 150-161.

Au, G., \& Choi, I. (1999). Facilating implementation of total quality management through information technology. Information and Management, 36(6), 287-299.

Awang, Z. (2012). Structural equation modelling using AMOS graphic. Shah Alam: UiTM Press.

Barendsz, A. W. (1998). Food safety and total quality management. Food Control, 9(2-3), 163-170.

Bidin, J. (2013). Malaysian halal market serving the global halal market with a difference. Malaysia Halal Industry Directory 2013, 33-36.

Bou-Llusar, J. C., Escrig-Tena, A. B., Roca-Puig, V., \& Beltrán-Martín, I. (2009). An empirical assessment of the EFQM Excellence Model: Evaluation as a TQM framework relative to the MBNQA Model. Journal of Operations Management, 27(1), 1-22.

Brah, S. A., Tee, S. S. L., \& Rao, B. M. (2002). Relationship between TQM and performance of Singapore companies. International Journal of Quality \& Reliability Management, 19(4), 356-379.

Che Din, R., \& Daud, S. (2014). Critical success factors of MS1500: 2009 implementation. Procedia-Social and Behavioral Sciences, 121, 96-103. 
Curkovic, S., Melnyk, S., Calantone, R., \& Handfield, R. (2000). Validating the Malcolm Baldrige National Quality Award framework through structural equation modelling. International Journal of Production Research, 38(4), 765-791.

Dale, B. G., \& Cooper, C. L. (1994). Introducing TQM: The role of senior management. Management Decision, 32(1), 20-26.

Dean, J. W. Jr., \& Bowen, D. E. (1994). Management theory and total quality: Improving research and practice through theory development. Academy of Management Review, 19(3), 392-418.

DeBaylo, P. W. (1999). Ten reasons why the Baldrige model works. The Journal for Quality and Participation, 22(1), 24-28.

Evans, J. R., \& Lindsay W. M. (1999). The management and control of quality ( $4^{\text {th }}$ ed.). Ohio: South-Western.

Evans, J. R., \& Lindsay, W. M. (2004). The management and control of quality ( $6^{\text {th }}$ ed.). Ohio: South-Western.

Hair, J. F., Anderson, E. R., Tatham, L. R., \& Black, C. W. (1998). Multivariate data analysis ( $5^{\text {th }}$ ed.). New Jersey, USA: Prentice-Hall.

Ho, S. K. (1995). TQM an integrated approach: Implementing total quality through Japanese 5-S and ISO 9000. London: Kogan Page Limited.

Hoang, D. T., Igel, B., \& Laosirihongthong, T. (2006). The impact of total quality management on innovation: Findings from a developing country. International Journal of Quality \& Reliability Management, 23(9), 1092-1117.

Hoque, A. S. M. M., Siddiqui, B. A., Awang, Z., \& Baharu, S. M. A. T. (2018). Exploratory factor analysis of entrepreneurial orientation in the context of Bangladeshi small and medium enterprises (SMEs). European Journal of Management and Marketing Studies, 3(2), 81-94. 
Lam, S. Y., Lee, V. H., Ooi, K. B., \& Phusavat, K. (2012). A structural equation model of TQM, market orientation and service quality: Evidence from a developing nation. Managing Service Quality: An International Journal, 22(3), 281-309.

Luning, P. A., Marcelis, W. J., \& Van der Spiegel, M. (2006). Quality management systems and food safety. In P. A. Luning, F. Devlieghere, \& R. Verhe' (Eds.), Safety in agri-food chains (pp. 249-297). Wageningen: Wageningen Academic Publishers.

Mohd Janis, Z. (2004). Halal food-production, preparation, handling and storage. Standard \& Quality News, 11, 2-3.

Mohd Mokhtar, S. S., Zien Yusoff, R., Abas, Z., Ahmad, H., Md Hussain, M. N., \& Othman, W. M. (2013). Aplikasi Sistem Pengurusan Kualiti Dari Perspektif Islam. UUM Press.

Oakland, J. S. (1993). Total quality management: The route to improving performance ( $2^{\text {nd }}$ ed.). Oxford: Butterworth-Heinemann Ltd.

Prajogo, D. I. (2006). Progress of quality management practices in Australian manufacturing firms. The TQM Magazine, 18(5), 501-513.

Prajogo, D. I., \& Sohal, A. S. (2004). The relationship between TQM practices, quality performance, and innovation performance: An empirical examination. International Journal of Quality \& Reliability Management, 20(8), 901-918.

Prajogo, D. I., \& Sohal, A. S. (2006). The integration of TQM and technology/R\&D management in determining quality and innovation performance: An empirical examination. Omega, 34(3), 296-312.

Psomas, E. L., \& Fotopoulos, C. V. (2010). Total quality management practices and results in food companies. International Journal of Productivity and Performance Management, 59(7), 668-687.

Psomas, E., Vouzas, F., \& Dimitrios, K. (2013). Quality management benefits through the "soft" and "hard" aspect of TQM in food companies. The TQM Journal, 26(5), 431-444. 
Riaz M. N., \& Chaudry M. M. (2004). Halal food production. Boca Raton, Florida: CRC Press.

Sharma, M., \& Kodali, R. (2008). TQM implementation elements for manufacturing excellence. The TQM Magazine, 20(6), 599-621.

Sila, I., \& Ebrahimpour, M. (2003). Examination and comparison of the critical factors of total quality management (TQM) across countries. International Journal of Production Research, 41(2), 235-268.

Syed Marzuki, S. Z., Hall, C. M., \& Ballantine, P. W. (2012). Restaurant manager and halal certification in Malaysia. Journal of Foodservice Business Research, 15, 195-214.

Tai, L. S., \& Przasnyski, Z. H. (1999). Baldrige award winners beat the S\&P 5000. Quality Progress, 32(4), 45-51.

Welikaka, D., \& Sohal, A. S. (2008). Total quality management and employee's involvement: A case study of an Australian organization. Total Quality Management, 19(6), 627-642.

Wilkinson, A., Allen, P., \& Snape, E. (1991). TQM and the management of labour. Employee Relations, 13(1), 24-31.

Yaakob, C. M., Jamil, B., Awis Qurni, S., \& Ahmad Nizam, A. (2007, October). Halal Hub Opportunities. Proceeding in 4th Asian Livestock and Feed Industry Conference, Kuala Lumpur, 25 October 2007.

Yusuf Ali, A. (2005). The meaning of Holy Quran: Text translation and commentary. Kuala Lumpur: Islamic Book Trust (IBT) Kuala Lumpur. 